\title{
A Report on "Portland Labor Players II: An Oral History/Theater Project"'
}

\section{Jerry Lembcke*}

Does "Bambi" tell the hunters" side of the story?

Does Steinbeck "s "Grapes of Wrath" tell the employer's side?

Does Uncle Tom's Cabin present the position of slaveowners?

Does Shakespeare give MacBeth and his wife a chance to explain why they slaughtered everyone in sight?

These editorial questions were asked by Oregon's major newspapers when a one-act play, "1934: Blood and Roses," was banned from the Oregon State Fair because "it presented only one side of the labor/management conditions that existed in the period depicted."

The play, performed by Portland Labor Players II, is the outgrowth of a six month project funded by the Oregon Committee for the Humanities and sponsored by the Pacific Northwest Labor College. The story line, developed from interviews with " 34 " men and women, focuses on two longshoremen families to portray the growth and strengthening of the workers" movement from the onset of the depression to the West Coast-wide longshoremen's strike in 1934. The corruption of the boss-controlled hiring hall, the veteran's bonus march, the firing on Senator Robert Wagner by the Portland Police (they thought he was a Red!), and the shooting of four strikers by police are among the scenes depicted in the play.

Influenced by Brechtian theater technique, the play is performed by a cast of six, one of whom is a narrator who moves in and out of scenes weaving together the historical threads of the period. The other five actors negotiate quick costume changes to portray cops, strikers, bonus marchers, President Hoover, radio reporters, wives, newsboys and scabs. A portable stage and versatile props horrowed from at radical theater group. Family Circus, allows the players to perform around the state in indoor and outdoor settings.

The play was originally scheduled for a small number of union picnics and

* The author was Project Director for Portland Labor Players II and humanities coordinator for Pacific Northwest Lithor College during the course of the project. He now lives in Madison. Wisconin 
public performances. The Longshoremen's union (ILWU) embraced the project from its inception and brought the play to its July 5th (Bloody Thursday) commemorative picnic. Since then the schedule has swelled with more requests than the players, all of whom work at other jobs, can meet. Within a month, performances were given Communications Workers (CWA) picnics in Portland and Seattle, Transit Workers in Portland, Longshoremen in Coos Bay. Oregon, the Plant Closures Organizing Committee in Eugene/Springfield, Eugene's Saturday Market and theaters in Ashland and Portland.

The State Fair controversy has brought the play still more notoriety. Shortly after the play had initially been accepted for a state fair appearance, a member of the fair's entertainment board, Bernard Richards, attended a performance and on July 22 recommended against the play"s acceptability. With that, the fur began to fly. State and local labor leaders, normally quiescent in the face of such controversies (especially in matters of culture!) rushed to the defense of Portland Labor Players II. State AFL-CIO President Bob Kennedy and COPE Director Nellie Fox fired off a letter to the fair board calling its action "unconscionable" and defending "19.34: Blood and Roses" as an excellent play based on historical facts. "This is the United States of America," they reminded fair organizers, "where freedom of expression is guaranteed by law-not a Communist dominated country where labor unions are banned." Longshoremen's local President Bill Luch wrote asking, "What the hell is wrong with one side of an issue being brought before the people?" All of the State's major newspapers editorialized against the Fair's "censorship."

Sensing they were in trouble, fair officials offered a compromise: they would rent space to the players. "No Way," answered Assistant Project Director Jerry Raitzyk who held out for the original arrangements to appear on the fair"s central entertainment stage. On August 6, State Senator Jim Gardner asked the state's Attorney General for an opinion on potential first amendment violations in the han and contacted the Governor"s office. Taking flak from all but their business friends, fair organizers backed down and reinvited Portland Labor Players II. On tour at the time, the group was reached, appropriately enough, at the Coos Bay Longshoremen's hall where it accepted a Labor Day engagement at the State Fair.

The political fireworks have overshadowed some very interesting historical dimensions of the project. Pacific Northwest industrial workers were mostly unorganized at the outset of the depression. Waterfront, woods and mill workers were especially hard hit by the economic collapse. Between 1930 and 1934 left-wing organizers had been busy building unity among Portland's unemployed and organizing community responses to utility shutoffs, rate increases for public services and the deportation of foreign born radicals. When the dock strike began on May 9. 1934, the organizational infrastructure built by the left paid off. The unemployed refused to scab; watresses handed out restaurant food to the strkers: prostitutes made their rooms available to ingle strikers subject to vagrancy arrests; farmers hauled in food to the strikers" families.

The attention showered on San Francisco's "Bloody. Thursday" events and 
charismatic leader Harry Bridges by historians, has overshadowed the coat-wide nature of the strike and Portland's importance in it. In Portland, four strikers were shot by police on July 11; organizer Dirk DeJonge, arrested for speaking to a rally of the unemployed, took his case to the U.S. Supreme Court which returned a landmark decision in his favor. But most importantly the Portland ' 34 strike paved the way for the organizing of the timber industry and the organizing of the International Woodworkers of America, the CIO's largest West Coast union.

The play also revives a long tradition of workers" theater in the Portland area. The very first dramatic performance recorded was that of a ship's crewmen docked in Portland in the 1850 s. Troupes traveling through mining camps continued the tradition through the 19th Century. In the early 1920s, the only theater in Portland was the Portland Labor College Players which conducted dramatic arts classes for working poeple and then utilized the "student" talent to perform wintertime plays. Throughout the 1930s and early 40s there were other attempts at pro-labor, anti-fascist theater.

The present endeavor is inspired by this tradition and also by recent theoretical and organizational developments. The attention given to the cultural dimensions of working class life by historians and sociologists during the $1970 \mathrm{com}$ bined with the political and theatrical advances made by groups like the San Francisco Mime Troup and Dakota Caravan have been combined in Portland Labor Players II to elevate political/worker's theater in the United States to a still higher level. The path being trod by the group is a narrow one winding through a graveyard filled with previous attempts to mix politics and art. On the one side of the path lie those whose politics were pure and audiences were small; on the other side lie those whose work was shaped by artistic instinct rather than informed by theory and history, and who found entertaining easier than educating.

As a type of political theater. Portland Labor Players II is unique in having the sponsorship of organized labor. The Pacific Northwest Labor College (PNLC). formed in 1977 is a labor owned and governed institution. Its humanities coordinator conceived the project as a way of delivering labor history to working class audiences and uniting socially conscious ant (and artists) with a politically receptive constituency. The marriage has been a mixed success. The "labor" response has been a curious one. Labor leaders are quich to give their verbal and written support to the project but slow to publicize the troupe's existence within their own organizations or do anything to turn out their membership for performances. Case in point was a performance for AFSCME while over 1, ooo Portlandarea county workers were on strike. The players perceived the performance as it strike support function but AFSCME leaders saw it as a treat for other union leaders-13 people attended. Even the AFL-ClO rescue from state fair censors is tainted with speculation that labor leaders only "used" the play issuc as a way to embarrass a Republican Governor against whom they have initiated at recall.

More positive has been the personal experience of the artists in the project. At the outset individuals involved would most often characterize themselves as socially conscious, but not political. Neither the project nor the play was ever de- 
fined by them or for them as political theater. Most "political" theater in the United States presupposes the involvement of already politicized artists; Portland Lahor Players II made no such presupposition, seeing instead that one legitimate political objective of theater is the growth and development of artists in all dimensions of their work-political and technical. The exposure to working class history, and non-traditional audiences plus the positive reception given to the players at post-performance socials in homes and union halls have all been forces for change within Portland Labor Players II.

One of the most gratifying results of the project has thus been the metamorphosis of the group itself. Troupe members now consider group priorities along with their own and have begun discussions leading to their reorganization as a collective. Members performing in other productions in the city have expressed a new discomfort with the sterility of more traditional formats and techniques. Summing up her experience in Portland Labor Players II, one member put it: "I'm not the same person 1 was when this started; and this isn"t the same group." 